\title{
Fazer ver e fazer falar: notas sobre 0 estilo filosófico de Merleau-Ponty
}

\author{
Leandro Neves Cardim \\ Universidade Federal do Paraná - UFPR
}

\begin{abstract}
RESUMO
Através da investigação destas duas figuras da retórica clássica na obra de MerleauPonty pretende-se verificar como ele as incorpora a sua filosofia. Para realizar esta tarefa o artigo compara passagens de todos os períodos de sua obra. Quando o filósofo usa estas figuras ele nos faz pensar nas relaçóes da pintura, do cinema e da literatura com a filosofia. Ao trabalhar estas questóes o artigo pretende não só conduzir uma interrogação de fundo sobre o modo como MerleauPonty trabalha com questóes tradicionais, mas também sobre o alcance da ontologia.
\end{abstract}

\section{PALAVRAS-CHAVE}

Estilo; Artes; Literatura; Retórica; Ontologia.

\begin{abstract}
Through the investigation of these two figures of classical rhetoric in Merleau-Ponty's work we intend to verify how he incorporates them into his philosophy. To accomplish this task the article compares passages from all periods of his work. When the philosopher uses these figures, he makes us think about the relations of painting, cinema and literature with philosophy. By working through these questions, the article aims not only to conduct a deep question about how Merleau-Ponty works with traditional issues, but also about the scope of ontology.
\end{abstract}

\section{KEY WORDS}

Style; Arts; Literature; Rhetoric; Ontology. 
Partimos de duas citaçóes extraídas de dois artigos de Sentido e não sentido (1948) que vão nos colocar em contato com o uso e o contexto em que Merleau-Ponty lança mão de duas figuras da retórica clássica. Depois de comentá-las de maneira sucinta, aproveitaremos seu poder de irradiação para analisar não só certo deslocamento interno ao uso das mesmas figuras em $O$ visivel e o invisivel, mas também o sentido filosófico do uso feito pelo filósofo. Ele lança mão delas quando quer fazer com que seu discurso seja de tal forma vigoroso que termine realizando tarefas fora do escopo da filosofia tradicional.

A primeira diz:

Boa parte da filosofia fenomenológica ou existencial consiste em se espantar com a inerência do eu ao mundo e do eu ao outro, a nos descrever o paradoxo e esta confusáo, a fazer ver o liame do sujeito e do mundo, do sujeito e dos outros, ao invés de explicá-las, como faziam os clássicos, por algum recurso ao espírito absoluto (Merleau-Ponty, 1996, p. 74).

A segunda diz:

Desde então a tarefa da literatura e da filosofia não podem ser separadas. Quando se trata de fazer falar a experiência do mundo e de mostrar como a consciência se escapa no mundo, náo podemos nos gabar de atingir uma transparência perfeita da expressão. A expressão filosófica assume as mesmas ambiguidades que a expressão literária, se o mundo é feito de tal modo que não só possa ser exprimido por histórias e como mostrado com o dedo (Ibid., p. 36-37).

Eis aí duas linhas de raciocínio que podem nos ajudar a precisar o ponto de vista filosófico de Merleau-Ponty: uma relativa ao espanto e à descrição, outra à tarefa e ao modo de expressáo da filosofia. Ele as usa quando se trata de tirar proveito da força do discurso filosófico. O primeiro trecho foi extraído do artigo "O cinema e a nova psicologia", e o segundo do artigo "O romance e a metafísica", ambos de 1945. No primeiro, a filosofia tem algo a aprender com o cinema e a nova psicologia. Esta ciência "nos faz ver no homem [...] um ser que está lançado e que está ligado [ao mundo] como que por um liame natural” (Ibid., p. 68). É graças a isto que a psicologia da forma nos "ensina novamente a ver o mundo com o qual estamos em contato através de toda a superfície de nosso ser" (Ibid.). O filósofo se espanta com isto. E uma vez no mundo da percepção e interpretando o filme como um objeto percebido, ele liga o sentido do filme à história que é contada, ao seu ritmo, à configuração espacial e temporal das coisas, ao fato de que o filme só remete a si mesmo, e que no próprio filme as ideias estáo em estado nascente. Além disto, é preciso dizer que o cinema se dirige ao "nosso poder de decifrar tacitamente o mundo ou os homens e de coexistir com eles" (Ibid., p. 73). É verdade que outras artes também 
possuem, cada uma a sua maneira, um poder de interpretação do mundo, mas no texto de Merleau-Ponty o cinema é interpretado como uma "maneira especial de ser no mundo" (Ibid., p. 74): o cinema nos faz ver a conduta, o gesto, o movimento, ele faz ver uma imagem sonora, falante e pensante movendo-se.

Para Merleau-Ponty a eficácia do cinema reside no fato de que ele nos mostra a conduta do exterior. Ao invés de explicar ou de perder a experiência, o cinema e a psicologia da forma no ajudam a ver, a reconhecer e a descrever a coexistência do corpo, do mundo e de outrem. O filósofo tem o que apreender com estas atividades porque ele recusa em explicar o mundo à maneira do pensamento objetivante. Ele quer aprender com o cinema a "fazer aparecer" o mundo (Ibid.). O cinema tem algo de especial para Merleau-Ponty porque ele considera que "o sujeito é cinematográfico por excelência” (Ibid., p. 75). O que vemos acontecer com este sujeito não é muito diferente daquilo que vemos acontecer no cinema: sua expressão está ligada ao cinema como meio de expressão e a descrição filosófica deve fazer ver como em um filme, ela faz aparecer e faz ver um mundo sensível, falante e pensante em movimento. Ao usar tal figura, Merleau-Ponty quer comunicar ao leitor a impressão de que o espetáculo descrito é visto como em uma tela de cinema. Seu texto não é neutro e sua posição pode ser aproximada àquela do diretor de cinema. Podemos ouvir isso nos comentários acerca da técnica do cinema. Há no artigo uma analogia que vale a pena reter. Para Merleau-Ponty é a montagem (seleção de planos) e a decupagem (seleção de cenas) que fazem do filme uma "forma extremamente complexa no interior da qual açóes e reaçóes muito numerosas se exercitam a cada momento, cujas leis devem ainda ser descobertas e só foram até aqui [1945] adivinhadas pelo faro ou pelo tato do diretor que maneja a linguagem cinematográfica como o homem falante maneja a sintaxe" (Ibid., p. 70).

Apesar das diferenças dos meios, o filósofo, o cineasta e o pintor querem fazer ver de fora. Eles não o fazem excluindo o lado de dentro. Não se trata de negar nem um nem outro. Merleau-Ponty cita Goethe na última frase do texto para nos fazer entender que os extremos estáo paradoxalmente relacionados: "o que está dentro também está fora” (apud., Ibid., p. 75). Como ver isto? Não será precisamente isto que o cinema e a filosofia terminam por nos fazer ver e entender? Talvez seja possível ouvir através da citação de Goethe ecos da ideia de que o sujeito é cinematográfico e que isto exige do filósofo um alargamento em seus modos de expressão. É preciso ouvir, também, esta ideia expressa na Fenomenologia da percep̧̧ão (1945): "o mundo está inteiramente dentro e eu estou inteiramente fora” (Id., 2016a, p. 469). Enfim, talvez possamos encontrar o rastro de algo a mais na citação de Goethe, algo que caracterizaria a primeira filosofia de Merleau-Ponty: a ambiguidade. Se por um lado o mundo é aquilo que aparece, por outro, o próprio mundo só aparece através da 
circunscrição do corpo enquanto sujeito desta percepção. A descrição merleau-pontiana envolve uma seleção de coisas que o filósofo sabe, por experiência, acentuar ou iluminar. $\mathrm{O}$ cinema ensina que a descrição não pode e não deve ser exaustiva. Mesmo que se tentasse algo assim através de uma descrição rigorosa, esta descrição seria inútil. A descrição praticada por Merleau-Ponty não pretende nem substituir nem coincidir com a realidade descrita. Náo é por acaso que a figura usada (fazer ver) apareça em um texto sobre o cinema, em um estudo sobre uma arte ligada ao mesmo tempo ao movimento e à manifestação de um objeto exterior cuidadosamente elaborado e preparado não só por um diretor, mas também por uma grande equipe.

Merleau-Ponty aproxima o cinema, a nova psicologia e o romance americano. Estas configuraçóes expressivas têm em comum a expressão do homem do exterior, elas estão de acordo quando, através delas, um comportamento se torna compreensível em um gesto apreendido de fora: "o cinema é, justamente, de todas as artes aquela que pode melhor exprimir o homem através do seu comportamento visível. Quando um romancista quer descrever a cólera ou o ciúme, ele pode fazê-lo 'do interior”' (Id., 2013a, p. 22). Em tal passagem ele reflete sobre o cinema e a literatura no registro dos seus dois primeiros livros. Lembremos que $A$ estrutura do comportamento (1942) diz que foram os pintores que "nos ensinaram, segundo a expressão de Cézanne, a olhar os rostos como pedras” (Id., 2013b, p. 253), ou seja, de fora. É isto que o método do espectador estrangeiro requer: conjugação de certa neutralidade descritiva e do trabalho crítico e interpretativo. Com este método o filósofo pretende ultrapassar o mundo objetivamente dado, este método torna visível o mundo humano da expressão através da colocação em relevo da estrutura de seu comportamento. Ele faz isto colocando-se no plano de exterioridade da forma sensível e cultural. Aqui, os comportamentos simbólicos aparecem sobre o fundo da natureza e o elemento exterior destes comportamentos os tornam irredutíveis ao pensamento clássico. Interessaria investigar como o trabalho da expressão se articula com o meio expressivo no interior de sua historicidade própria; para aplicar o método do espectador estrangeiro ao estudo das diferentes artes seria preciso colocar em relevo o modo como cada obra se articula com seu modo de existência próprio. Quem póe em prática este método, quem descreve e compreende a experiência dos objetos culturais do exterior, descobre que a arte ultrapassa os limites do meio e se torna "a percepção de um "universo"' (Ibid., p. 266), de um mundo de realidades percebidas.

$\mathrm{Na}$ Fenomenologia da percepçáo a psicologia e outras formas de conhecimento fornecem ocasióes para avançar, do interior, na direção da reflexão que toma consciência de sua própria vida irrefletida. Situando-se no interior do sujeito que percebe o filósofo compreende que deste ponto de vista a experiência espontânea, a experiência das artes em geral, os saberes adquiridos das ciências humanas e da filosofia 
fenomenológica, o convidam a conceber e a expandir a coexistência entre o corpo, o mundo e os outros. Para o que nos interessa seria preciso tematizar a experiência do objeto cultural no interior do mundo vivido; seria preciso, também, recolocar neste mundo a abordagem tradicional de cada um dos modos de expressáo; seria preciso compreender que a filosofia é uma possibilidade criativa como as outras. Por enquanto, basta observar que no registro deste livro Merleau-Ponty não deixa de começar suas análises pelo estudo das condutas patológicas. Quando Schneider ouvia uma história ou ele mesmo contava uma, a única coisa presente era o imediatamente dado, ele não chegava a "viver" a história. Para que uma história possa ser vivida do interior ela deve possuir um "conjunto melódico com seus tempos fortes, seus tempos fracos, seu ritmo ou seu curso característico" (Id., 2016, p. 166). Já o leitor deve ser capaz de dar corpo e voz à narraçáo. A narrativa está ligada ao estilo e o leitor tem o poder de vivê-la do interior: "o sujeito 'compreende' porque tem o poder de viver, para além de sua experiência imediata, os acontecimentos indicados pela narrativa" (Ibid.). A análise da percepção da narrativa mostra que ela exige do leitor a recriaçáo de um mundo. Para a pessoa normal trata-se sempre de um mesmo processo através do qual há motivação e "retomada do exterior no interior e do interior pelo exterior" (Ibid.). Não se trata de negar a experiência imediata. Não se trata de negar também que por trás deste poder de ir além das significaçôes dadas há o Cogito tácito. Trata-se apenas de frisar certa materialidade e alcance do estilo de uma narrativa. Podemos dizer que Merleau-Ponty quer apreender e retomar o modo com que a narrativa se forma e se formula. Mas este processo não é muito diferente daquele que anima o filósofo no trabalho da escrita. Para a filosofia merleau-pontiana a reflexáo é uma experiência que se recolocou no mundo, uma experiência que não se considera onipotente e assume a tarefa da expressão: "o Cogito tácito só é Cogito quando se exprimiu a si mesmo" (Ibid., p. 466).

No segundo trecho, Merleau-Ponty atribui à filosofia a capacidade de criar. Assim como a literatura, a filosofia faz falar a vida e dá a ver uma criação, ela sedimenta. Ele aproxima a literatura, a filosofia e a política graças a certa fixação do mundo. Esta ideia implica o fato de que a experiência fixada ou formulada pela filosofia não fala sobre o mundo como o pensamento racional, ela não é demonstrativa. A filosofia faz falar graças a sua proximidade como a literatura. Ao invés de demonstrar, a filosofia narra, mostra e faz agir: tudo se passa como se ela pusesse o mundo diante do ouvinte e o fizesse ver mais do que aquilo que ele vê, a filosofia ao mesmo tempo ressalta a especificidade espaço-temporal do mundo e exibe as virtudes expressivas da própria criação filosófica. Escritor e filósofo estabelecem uma comunicação consigo mesmo e com o outro no momento em que narram uma experiência e reportam-se a um mundo. Não é só na recusa da transparência da expressão que eles 
convergem; também há convergência quanto a característica criadora e a especificidade linguística. A singularidade de cada um dos modos de expressão não exclui a convergência de todos eles com relação a uma ambiguidade fundamental. Quanto às modalidades ou às configuraçóes expressivas da palavra, tratar-se-ia de insistir no fato de que elas dão voz a um falante e mostram a expressão criadora. Elas ao mesmo tempo incorporam (fazem falar) e indicam (com o dedo indicador estendido!) o modo como o falante vai além das significações disponíveis. O próprio mundo não poderia ser exprimido de forma diferente, já que a fala retoma e lança adiante a riqueza expressiva do mundo, particularmente do mundo falante. Merleau-Ponty usa esta figura (fazer falar) em um discurso que pretende colocar em movimento e articular o que aparece na fala. Ele faz isto em um texto marcadamente filosófico que reflete sobre suas relaçóes com a literatura.

$\mathrm{Na}$ primeira citação, fazer ver se liga à descrição e ao espanto que caracterizam a filosofia, esta figura também está ligada ao nosso poder de decifração de um objeto que pode ser visto e interpretado de fora. Na segunda, fazer falar remete à tarefa e ao modo de expressão da filosofia, indissociável do nosso poder de viver do interior o sentido de uma narrativa estreitamente ligada ao estilo. Em uma o que impressiona é o sentimento de ter as próprias coisas diante dos olhos, na outra é fazer falar as próprias coisas.

Há uma passagem da Fenomenologia da percepção que não pode deixar de ser mencionada. Ela ajuda a avaliar, por contraste, a distância dos primeiros textos relativamente aos últimos. Quando se trata de descrever o enraizamento da consciência no ser e no tempo Merleau-Ponty afirma uma ambiguidade radical entre o sujeito como presença absoluta a si e os emblemas que o próprio sujeito se dá na sucessão e na multiplicidade (Ibid., p. 489). Estes emblemas e mesmo as essências da linguagem repousam na vida antepredicativa da consciência. É precisamente aí, no silêncio da consciência originária, que o filósofo vê aparecer não só aquilo que as palavras querem dizer, mas aquilo que as coisas querem dizer (Ibid., p. 16). Entâo ele diz: "aqui brota uma luz, aqui não tratamos mais com um ser que repousa em si, mas com um ser do qual toda essência, assim como a da luz, é fazer ver" (Ibid., p. 489). Está aí, no registro deste livro, o ser ou a luz que faz ver. Se antes era preciso que o cogito tácito se exprimisse para existir, agora, vemos a subjetividade fazer ver sem palavras, uma subjetividade que ilumina as palavras ou que se projeta nelas. A subjetividade seria silenciosa e o padrão para medir as significaçóes da linguagem, ela estaria antes e seria a condição da fala, já as palavras seriam apenas a tradução deste silêncio originário da consciência. Neste livro o filósofo trabalha explicitamente com duas definiçóes: "o ser como o que nos aparece e a consciência como fato universal" (Ibid., p. 455). Essa proximidade na formulaçáo daquilo que é o ser e a consciência, ajuda a frisar a 
correlação: através da percepçáo reencontramos a espessura ontológica da nossa experiência, mas é preciso acrescentar que o ser é aquilo que aparece para qualquer sujeito habitante do mundo. Para aproveitar a metáfora da luz seria interessante explorar suas relaçóes com as trevas ou com aquilo que ela não é: os objetos culturais, as palavras, que essa luz ilumina mas sem as quais ela mesma não faz ver. $\mathrm{O}$ poder que esta luz tem de fazer ver, de iluminar a escuridáo do ser em si e fazer entender que o mundo cultural não está atrás de nós mas nosso horizonte, delimita aquilo que ela consegue e pode ver. Isto implica não só em um ponto cego, mas também em uma atitude que deixa na sombra o mundo que pretendia iluminar. $\mathrm{O}$ mundo que esta luz faz ver não se sustenta porque não há mediação consciente e explícita do substrato da linguagem. Em seus últimos textos, particularmente nas notas para a obra póstuma e inacabada O visivel e o invisivel (1964), Merleau-Ponty considera esta postura ingênua. Segundo o próprio filósofo, haveria aí a postulação de um "cogito silencioso que seria adequação à consciência silenciosa, ao passo que a descrição do próprio silêncio repousa inteiramente sobre as virtudes da linguagem" (Id., 2016b, p. 230). A ingenuidade não está apenas na concepção através da qual se liga o cogito silencioso e sua expressão, ela também se encontra no desconhecimento de uma concepção mais radical segundo a qual a filosofia faz falar o silêncio do mundo através de uma retomada dos sedimentos da língua, da linguagem sedimentada e da história. A tela em que o filósofo projeta seu filme é o texto escrito.

O emprego desta figura (fazer ver) deve ser a ocasião de um esclarecimento. É Heidegger, em Ser e tempo (1927), quem torna explícito o uso ontológico desta figura como método de descrição fenomenológica. É ele quem diz, ao comentar Aristóteles, que o discurso "faz ver algo" (Heidegger, 1985, p. 45), que o discurso torna manifesto aquilo que é falado a quem fala e ouve. Com isto ele quer evitar o fechamento do conceito de verdade em um tipo de teoria lógica da proposição. A fenomenologia que salta destas páginas pode ser caracterizada através da máxima do retorno "às coisas mesmas". Ela quer fazer ver a coisa mesma, ela quer manifestar o ser de maneira intuitiva e originária; a palavra "mesmas" sugere o aspecto intuitivo e originário da experiência do ser. Vem daí que esta palavra aponte para aquilo que Merleau-Ponty chama de "descrição direta" (Merleau-Ponty, 1996, p. 94). Vem daí, também, a "diferença absoluta" (Id., 2016b, p. 314) estabelecida pelo filósofo alemão entre o ôntico e o ontológico. Vem daí, enfim, a elaboração nostálgica de um discurso que pretende manifestar a automanifestaçáo do ser. Este ponto é importante porque, no curso A filosofia hoje (1958-1959), Merleau-Ponty diz que há "razôes de princípio que tornam impossível a tarefa designada pelo Prefácio de Ser e tempo" (Id., 1996, p. 92). Qual é esta tarefa? Segundo Merleau-Ponty, tratar-se-ia da "retomada mais radical da interrogação metafísica sobre o Ser" (Ibid.), mas para o filosofo 
francês é a própria natureza da "filosofia", da "verdade" e de "nossa língua" que torna impossível esta tarefa. Merleau-Ponty recusa essa "filosofia direta" por várias razóes, mas neste ponto ela aparece como não sendo radical, ela não coloca a si mesma em questão e por isto mesmo não toma consciência de suas dependências; ela usa dogmaticamente o conceito de essência. É verdade que a filosofia se identifica, para Merleau-Ponty, com "investigação do Ser ou do Ineinander [um-no-outro]" (Ibid., p. 156), mas é verdade, também, que para ele é preciso explorar as "regiōes do Ser" e jamais perder o contato com os "seres" (Ibid., p. 156). O filósofo francês assume a investigação do ser com tarefa da filosofia, mas sua própria filosofia considera o ente como absolutamente necessário: "é talvez uma lei da ontologia ser sempre indireta, e só conduzir ao ser a partir dos seres" (Id., 1968, p. 125). Em contraste com Heidegger que pretende restituir nossa presença à coisa mesma, Merleau-Ponty faz um desvio determinante pelos seres regionais.

Há um lugar muito importante para o ser na filosofia de Merleau-Ponty, mas é preciso insistir que, para ele, não há o estabelecimento de um acesso direto ao ser reservado a alguns privilegiados. À medida que sua filosofia se desenvolve ele trabalha mais deliberadamente com a intenção de exprimir o ser através das palavras, através do contato com os seres da natureza, da ciência, da vida privada e pública. Toda a sua obra termina sendo prova disto. Merleau-Ponty nunca acreditou ser possível “alcançar o ser sem passar pelo fenômeno" (Id., 2016a, p. 457), pelo empírico e pelo ôntico. No período intermediário, ao tematizar a categoria da expressão na linguagem, ele tem a oportunidade de precisar sua posição. No curso Investigaçóes sobre o uso literário da linguagem (1953), em um trecho que trata das relaçóes entre a linguagem e a literatura na obra de Stendhal ele diz, de maneira muito breve, qual é a "estranheza da expressão": ela consiste em "fazer falar as coisas" (Id., 2013c, p. 209). Neste mesmo curso ele enfatiza a ficção literária e a comunicação poética. Ele analisa detidamente a obra de Valéry nesta direção e diz que há uma "ductilidade" da linguagem: ela possui um "poder de articular e de fazer ver através dos signos" (Ibid., p. 138). Dito de outro modo: a linguagem é elástica e plástica. Vem daí a valorização dos signos para se fazer ver e falar.

Através destas duas expressóes - fazer ver e fazer falar - Merleau-Ponty opera com duas figuras de pensamento da retórica clássica. Figuras que estão na categoria das figuras de imaginação: a hipotipose ou a descrição e a prosopopeia ou a evocação, personificação. Ele usa estas figuras em uma escrita filosófica. Vale dizer que o uso filosófico da retórica é antigo e remete ao Fedro de Platão, à Retórica de Aristóteles, mas também ao Kant da Terceira Crítica entre tantos outros. Este pano de fundo é decisivo para compreender o sentido do uso merleau-pontiano destas figuras, mas importa, aqui, chamar atençáo para uma fonte mais contemporânea do filósofo francês. 
Merleau-Ponty comenta algumas ideias de Paulhan em A prosa do mundo (19511969). Paulhan é alguém que explicita a metamorfose das palavras em pensamentos e dos pensamentos em palavras. Isto extrapola os quadros teóricos dos primeiros textos que mantinham certa distância e exterioridade entre os termos. MerleauPonty aceita a formulação que Paulhan faz do problema: a linguagem é comparável ao olho que faz ver todas as coisas, mas neste exato momento o próprio olho não se vê (Id., 2012, p. 163). A saída filosófica é fazer a reflexão entrar na linguagem, pois agora ela recusa não só a decomposição da língua e a fundação da linguagem, mas também o contato mudo de si a si. É o uso da linguagem no presente, o uso atual no gerúndio, que fornece a perspectiva de conjunto da língua, é na fala e na escrita que os elementos da língua realizam a comunicação. A linguagem está em movimento com as palavras. Merleau-Ponty não precisa mais lançar mão quer de uma subjetividade silenciosa, quer de uma linguagem que rompa o silêncio da subjetividade. A atividade falante repousa sobre a fala e as palavras.

Em A prosa do mundo Merleau-Ponty se refere ao livro As flores de Tarbes (1941) de Paulhan. Em um outro texto de Paulhan - Tratado das figuras (1949) -, podemos encontrar uma abordagem das figuras em questão. Merleau-Ponty não faz referência a este texto, mas vale a pena tê-lo em mente antes de continuarmos a discussão. Há hipotipose ou descrição quando a figura "pinta os objetos 'com traços tấo impressionantes que pensamos tê-los diante dos olhos" (Paulhan, 1997, p. 129). A prosopopeia anima ou dá "vida aos objetos, às abstraçóes, aos mortos, aos homens que ainda não nasceram" (Ibid., p. 129). Em suma: a descrição pinta e a evocação anima. Quintiliano nos diz que através da hipotipose o escritor se torna um pintor, de tal modo que as palavras dão "a impressáo de mais serem vistas do que ouvidas" (Quintiliano, 2016, p. 423). Aqui a vivacidade dos fatos e das personagens é o principal. Ele diz que a prosopopeia é a "figura mais ousada e de maior fôlego" (Ibid., p. 415). Esta figura personifica, ela faz um personagem falar no interior de um discurso: através dela "desvendamos os pensamentos dos nossos adversários, como se falassem consigo mesmos" (Ibid.). O que impressiona aqui é sem dúvida a dinamicidade do pensamento e da linguagem, a tal ponto que por vezes os textos nos dão a impressão de que um pensamento os anima. Como diz Cícero, através da animaçáo temos uma "figura que dá aos seres mudos e imateriais, uma linguagem, uma forma, e os faz agir ou falar" (Cícero, 1835, p. 359). Com a descrição as coisas parecem estar vivas como em uma pintura ou em um filme, com a animaçáo as coisas ganham vida através de um pensamento e uma fala como na leitura de uma narrativa literária. Merleau-Ponty usa filosoficamente estas figuras. É bom insistir nisto porque ele quer fazer papel de filósofo que pode ser comparado a um pintor e a um escritor. 
Para aprofundar o uso merleau-pontiano destas figuras vale a pena lançar mão de duas citaçóes de $O$ visivel e o invisivel (1964):

Se o filósofo interroga e entáo finge ignorar o mundo e a visáo do mundo que sáo operantes e se fazem continuamente nele, é precisamente para os fazer falar, porque ele crê neles e porque ele espera deles toda sua ciência [...]. Por enquanto é suficiente fazer ver que o Ser único - a dimensionalidade à qual pertencem os momentos, as folhas e as dimensões -, está além da essência e da existência clássicas e torna compreensível suas relaçôes (Merleau-Ponty, 2016, p. 18; 155).

Muitas coisas se interpóem entre aquelas primeiras citaçóes e estas, mas MerleauPonty continua fazendo profissão de filósofo, agora de modo mais radical. Na primeira ele usa aquela figura no intuito de precisar a tarefa interrogativa da filosofia e dar a entender que a fala vem do mundo e se dirige a ele. Tratar-se-ia de mostrar que o filósofo quer explicitar a experiência do mundo e que por isto mesmo ele náo se retira do mundo. Para compreender esta atitude em que se finge ignorar o mundo e seu ponto de vista sobre o mundo, é preciso observar que náo se trata mais de comentar a correlação entre a percepção que fornece a espessura de nossa relação com o ser e o ser como aquilo que aparece na experiência perceptiva. Este fingimento faz parte do método do merleau-pontiano que, diga-se de passagem, trabalha desde o início simultaneamente com Bergson e Husserl. Desde 1945 ele lança mão deste método de fingimento que prevê uma atitude que apresenta o mundo da percepçáo como anterior ao objeto cultural, particularmente a linguagem. Ele mesmo comenta que "fingia", em uma espécie de "abstração metodológica", encontrar-se no "mundo mudo da percepção" (Id., 2000, p. 22). Em O visivel e o invisivel não se trata de abandonar a atitude de fingimento tipicamente bergsoniana, mas de enfatizar a crença do filósofo no mundo e na sua visão de mundo. Esta mudança revela algo sobre a interrogação filosófica.

A crença no mundo de que fala a primeira citação é uma experiência que não opóe os dois lados da questão. Não se trata mais de comentar o alcance da consciência perceptiva, mas de considerar a existência de um tipo de ser que não exclui dimensóes que escapam à percepção. Trata-se não só de fazer falar o Ser através da filosofia, mas também de interpretar a filosofia como o "Ser falando em nós" (Id., 2016b, p. 247). Notemos que na citação o vetor do uso da figura analisada mudou: não é mais da subjetividade que se faz falar ou que se ilumina o mundo e as palavras. A interrogação faz falar o mundo ou o Ser porque ela fala do seu interior, porque o Ser vem primeiro e porque o Ser se faz continuamente através da interrogação do filósofo. MerleauPonty nos diz como é preciso compreender a interrogação: "como relação última com o Ser e como órgão ontológico” (Ibid., p. 171). Enquanto filósofo, Merleau-Ponty interroga o ser através dos entes e formula sua interrogação de maneira escrita. Sua 
reflexão deve ser compreendida como instrumento que se serve da linguagem para descrever e compreender as diferentes camadas do ser. Agora o filósofo trabalha de tal modo que a linguagem "codetermina o sentido último" da "série de camadas do ser selvagem" (Ibid., p. 230). A interrogação filosófica exprime e fixa o mundo, e para realizar esta tarefa o filósofo usa a linguagem de tal modo que é possível "fazer falar as próprias coisas" (Ibid., p. 164). Ele faz falar as coisas através de uma mediação e de uma articulação que implicam um uso criador da língua e da linguagem.

$\mathrm{Na}$ segunda citação a audácia consiste em que a filosofia faz ver ou pinta com palavras a dimensionalidade do Ser. Merleau-Ponty parte de um relevo ontológico, ele parte da ideia de um "há prévio" que é sublimado ou realizado pela filosofia. É verdade que ele descreve a deiscência do sensível e tudo aquilo que implica o ver e o visível, a visão e a visibilidade, a imbricação entre quem vê e sua inerência ao que é visto. Mas é verdade, também, que ele não para por aí. Como ele diz em uma nota à margem do texto inacabado O visivel e o invisivel: "Nossa tese: é preciso este HÁ de inerência, e nosso problema [é] mostrar que o pensamento, no sentido restritivo (significação pura, pensamento de ver e de sentir) só se compreende como realização, por outros meios, do voto do HÁ, pela sublimação do HÁ e a realização de um invisível que é exatamente o avesso do visível, a potência do visível” (Ibid., p. 188). Tal passagem ajuda a entender o fato de que também a filosofia é a realização de um invisível, ela faz ver com palavras o avesso do visível, ela é criadora. A filosofia fixa, formula, dá testemunho de uma experiência. Aqui também o vetor da análise mudou: não é mais a subjetividade que faz ver, mas as palavras. Em novembro de 1960, ao abordar a questão das relaçôes entre a filosofia, a política e a literatura, ele faz a seguinte observação sobre a filosofia: "o que ela diz, suas significaçôes, não são o invisível absoluto: ela faz ver com palavras. Como toda a literatura. Ela não se instala no avesso do visível: ela está dos dois lados" (Ibid., p. 313). Longe de se instalar no avesso do visível, mas trata-se de realizar ou de fazer ver o Ser único com palavras, e para isso é preciso trabalhar dos dois lados. Se não há diferença absoluta entre filosofia e literatura, mas isto não quer dizer que a filosofia se transforme em literatura. Assim como a fala do filósofo não é "absolutamente pura" a do escritor não é "puramente filosófica” (Ibid., p. 314). É graças ao trabalho com as palavras que o filósofo faz papel de filósofo, que ele não perde a "sua profundidade" (Ibid.). O poder e as significaçôes da filosofia são inseparáveis das palavras.

Nos últimos textos, é possível circunscrever uma circularidade entre a criação e o procedimento indireto da filosofia, entre a expressão da experiência muda de si e a formulação de um acesso, uma realização, uma adequação. Nesses textos e notas é possível perceber que há na filosofia uma “inscrição do Ser" (Ibid., p. 248), uma criação que é simultaneamente inclusão e registro do Ser. Isto é possível por dois 
motivos: em primeiro lugar, porque a própria filosofia é interpretada como "criação no sentido radical: criação que ao mesmo tempo é adequação, a única maneira de obter uma adequação" (Ibid.). Trata-se de uma criação que é ao mesmo tempo chamada e engendrada pelo Ser universal, criação que prolonga e dá testemunho deste Ser (Ibid., p. 225); criação (atividade que faz existir) que é ao mesmo tempo "reintegração do Ser" (Ibid., p. 247). Em segundo, porque "o Ser é o que exige de nós criação para que dele tenhamos experiência" (Ibid., p. 248). Aqui, filosofia e arte "juntas" nos colocam em "contato com o Ser" porque não são reproduçóes, mas criações. Elas não são simples "fabricações arbitrárias" de coisas que habitam o mundo cultural (Ibid.). A filosofia é criação e adequação, mas é o Ser que exige do filósofo uma criação para que haja esta experiência do próprio Ser: há circularidade entre a filosofia como um "produto extremo do mundo" (Ibid., p. 222) e o mundo ou Ser que ela desvela.

Em "Notas sobre Claude Simon” (1960-61) encontramos, de início, uma consideração sobre a visão. Náo faltam na obra de Merleau-Ponty consideraçóes sobre a visão, mas nestas notas ela aparece como "visão de visionário": "ver é a permissão de não pensar a coisa, já que a vemos" (Id., 2000, p. 311). Quando simplesmente vemos e não pensamos já somos seres que olham para o mundo de tal modo que há uma espécie de retomada e abertura de novos horizontes. Guardando as devidas proporçôes, aquilo que acontece com o pintor não é algo absolutamente diferente, pois ele recolhe e lança a diante a tradição da pintura. A diferença está em que, ao revelar os meios visíveis através dos quais o mundo se mostra, o olhar do pintor retoma questóes mais precisas: a questão da luz, das sombras, dos reflexos e das cores. As questóes remetem a objetos que possuem apenas uma "existência visual", pois como $\operatorname{diz} O$ olho e o espirito (1960), eles são como "fantasmas" (Id., 1999, p. 29). O pintor interroga o mundo com seu olhar e a pintura nos faz ver aquilo que sem o pintor permaneceria invisível: "o olhar do pintor lhes pergunta [aos objetos ou aos fantasmas da pintura] como se arranjam para que haja de repente alguma coisa, e essa coisa, para compor um talismã do mundo, para nos fazer ver o visível" (Ibid.).

A vontade de fazer ver e fazer falar não é privilégio de quem usa as palavras. Em $O$ olho e o espirito Merleau-Ponty diz, por exemplo, que para o pintor "basta um pouco de tinta para fazer ver florestas e tempestades", que a pintura "faz falar o espaço e a luz que estáo ali” (Ibid., p. 59). O pintor recria a visibilidade através de seu olhar, suas mãos e agenciamentos de cores, ele liberta os fantasmas cativos da visão profana ao nos fazer ver algo, ele faz falar os elementos da pintura. No contexto da discussão sobre a pintura na obra de Merleau-Ponty vale a pena ter em mente a frase do pintor Marchand que ele menciona: 
Em uma floresta, senti muitas vezes que não era eu que olhava a floresta. Senti, certos dias, que eram as árvores que me olhavam, que me falavam... Eu estava ali, escutando... Penso que o pintor deve ser traspassado pelo universo e não querer traspassá-lo... Espero estar interiormente submerso, sepultado. Pinto talvez para surgir. (apud., Id., 1999, p. 31)

É o comentário de Merleau-Ponty que nos interessa, pois trata-se para ele de chamar a atenção para o fato de que em pintura devemos tomar a palavra "inspiração" ao pé da letra: "há verdadeiramente inspiração e expiração do Ser, respiração no Ser, ação e paixão são tão pouco discerníveis que não sabemos mais quem vê e quem é visto, quem pinta e quem é pintado" (Id., 1999, p. 31). Em suma: é o Ser que os elementos da pintura fazem falar e ver, é o Ser que olha e fala ao pintor, é o Ser que pintor escuta e olha, é o Ser que atravessa o pintor e é do interior do Ser que ele pinta para se fazer enquanto pintor, é o Ser que torna as coisas tão pouco discerníveis e exige o surgimento do pintor como que da morte, da sepultura, é daí que o pintor surge quando modula os elementos da pintura.

Quando é um escritor que fala daquilo que vê ou não, quando alguém usa a linguagem sedimentada de modo criador e desvela indiretamente sua experiência através da escrita, esse uso mostra que a "linguagem é um ser, um mundo" (Id., 2000, p. 312). Uma das notas sobre Simon registra, depois de uma conversa com o escritor, que sentir e viver literariamente não é nada "imediatamente dado", mas algo que "se desenvolve pelo trabalho": "Sentir, viver, a vida sensorial é como um tesouro, mas que não vale nada enquanto não há trabalho. $\mathrm{O}$ trabalho consiste não só aliás, em 'converter em palavras' o vivido; trata-se de fazer falar o que é sentido [faire parler ce que est senti]" (Ibid., p. 313). Merleau-Ponty pretende fazer falar o mundo através do trabalho de uma interrogação filosófica que tem um enorme interesse pela literatura. Afinal, a literatura vem e se dirige a uma "região aquém das ideias", ela tem uma "função insubstituível”: "pois aí está o sólido, é aí que está o durável, é aí que está o Ser - Insubstituível para a própria filosofia” (Ibid.). Seria interessante desenvolver a ideia de que há uma "filosofia espontânea, [um] pensamento fundamental particularmente na literatura" (Id., 1996, p. 391).

Nos últimos textos o ser aparece imbricado com a fala e o filósofo é alguém que fala e escreve. Mas o filósofo também é alguém que compreende que não somos nós que falamos do ser, mas "o ser que se fala em nós" (Id., 2016b, p. 244). Isto não equivale a uma "expressão direta do fundamental" (Id., 1968, p. 156) ou a uma "expressão direta do ser" (Id., 1996, p. 148). Como exprimir o ser filosoficamente? Merleau-Ponty defende que "é preciso tentar a expressão indireta, isto é, fazer ver o Ser através dos Winke [signos] da vida, da ciência, etc." (Ibid.). O filósofo deve lançar mão dos signos e assim nos faz ver a "dimensionalidade universal que é o Ser" (Id., 
2016b, p. 313). Apreendido pela filosofia, o Ser é aquilo que contém "tudo o que será jamais dito cabendo a nós criá-lo" (Ibid., p. 222). Seria interessante desenvolver esta circularidade na direção da investigação do sentido ontológico da carne e do conceito de reversibilidade como "verdade última" (Ibid., p. 201), afinal, nos últimos textos é desta reversibilidade que brota o "raio de luz natural que ilumina toda a carne e não apenas a minha" (Ibid., p. 185).

A questáo que gostaríamos de deixar no ar antes de terminar gira em torno da possibilidade de questionar o peso deste "Ser universal" que a filosofia deve "desvelar" (Ibid., p. 222). Como colocar isto em questão sem negar as aquisiçôes filosóficas do século XX? Não se trata de negar este ser, mas de minimizar sua importância e relativizar seu lugar relativamente ao discurso, ou seja, na relaçáo da linguagem com o ser falante. Já vimos que para Merleau-Ponty nossa "relação como o Ser se dá através de um ser" (Ibid., p. 152). Além disto, vale frisar que o filósofo e o escritor são personagens ligados à fala e à escrita e que eles "não podem declinar as responsabilidades do homem falante" (Id., 1999, p. 14). Vimos, enfim, que o filósofo deve tentar uma expressão indireta do Ser, ele deve fazer ver e falar o ser através de signos.

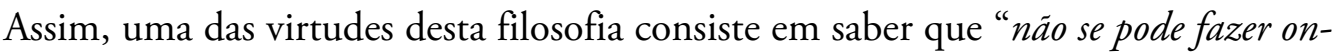
tologia direta. Meu método 'indireto' (o ser nos entes) é o único conforme ao ser" (Id., 2016b, p. 231). Não se trata de recusar estas aquisiçóes: não podemos recusar a ideia de que, para a filosofia, o Ser está entrelaçado ao mundo sensível, aos saberes e à história. Merleau-Ponty retoma esta ideia no curso $A$ filosofia hoje: "o ser se oculta como ser se fazendo ente" (Id., 1996, p. 119). Ele também retoma a ideia de que estamos "condenados ao ser" (Ibid., p. 121), ideia que já encontramos em 1945 quando ele diz: "só posso fugir do ser para o ser", "não posso sair do ser" (Id., 2016a, p. 418, 460). Certo, mas será que se adotarmos este ponto de vista nós podemos nos contentar com a interpretação que Merleau-Ponty faz do chiste poucas páginas depois neste mesmo curso sobre $A$ filosofia hoje?

Em 1905, Freud já se tinha dado ao trabalho de escrever todo um livro sobre $O$ chiste e sua relação com o inconsciente. Não se trata de entrar nesta questão, mas apenas de apontar para a linha merleau-pontiana de interpretação. No curso A filosofia hoje, em uma parte intitulada "Ser e fala", ele comenta a "extraordinária impressáo" que temos não nas decisóes, mas em certas açóes ou falas decisivas. Eis o que acontece neste momento: por um lado, "essas falas são tiradas de nós pelas coisas ou pelos outros" e a língua ultrapassa o falante, por outro, "elas são nós mesmos no mais alto grau” e ninguém seria capaz de dizê-las em nosso lugar (Id., 1996, p. 134). O filósofo acrescenta: "isto já é verdade no chiste que é espírito das palavras [mot d'esprit qui est esprit des mots]" (Ibid.). A tradução literal revelaria mais claramente a inversão operada e que é clara na língua francesa. Inversão ou jogo que faz o chiste derivar de uma 
atividade mais ampla e vasta do que naquela em que ele ocorre. $\mathrm{O}$ chiste já tinha sido exaustivamente estudado por Freud. Mas a interpretação merleau-pontiana não segue a linha freudiana. Impregnado pela atmosfera do ser ele diz o seguinte sobre o chiste: "não somos nós que jogamos, é o ser da fala que joga conosco" (Ibid.). O jogo em questão é ocasião para o filósofo reconhecer na vida da linguagem uma "profundidade" (Ibid.). O que interessa a Merleau-Ponty é o modo através do qual as "significaçóes superficiais da palavra nos levam a dizer algo que tenha mais sentido do que nós poderíamos saber ao considerar essas significaçóes associadas 'fortuitamente' em uma mesma palavra" (Ibid.). Para caracterizar este estilo merleau-pontiano de interpretaçáo filosófica podemos laçar mão do título do livro de Freud para fazer uma analogia. Se fosse preciso escrever um texto sobre a leitura merleau-pontiana do chiste ele poderia se chamar $O$ chiste e sua relaçâo com o ser.

Para problematizar isto sem sair do continente grego da ontologia basta lembrar da velha querela entre Parmênides e Górgias. Lembremos, de passagem, que foi em um poema que o ser e o não-ser foram enunciados pela primeira vez, e que ao assumir este ponto de vista pode ser que a ontologia termine tomando consciência de que ela mesma é um discurso. Não se trata de negar o ser, mas de confrontá-lo com o dizer. Seria preciso fazer um contraste mais detalhado entre a postura merleaupontiana segundo a qual é o ser que nos reivindica e interpela através da linguagem (Id., 1996, p. 135) e a postura que considera o ser como um efeito do dizer. Não se trata de desenvolver isto aqui, mas podemos, por exemplo, lembrar de Lacan que náo negava a obra de Merleau-Ponty nem a ontologia. Mesmo assim ele diz: "o discurso do ser supóe que o ser seja, e é o que o mantém"; ele também diz que o ser é "um fato de dito" (Lacan, 1975, p. 107, 108). Para esclarecer isto podemos lembrar, enfim, das consideraçóes de Cassin sobre a psicanálise e a sofística. Estas passagens de Lacan aparecem em vários textos de Cassin, e isto, sempre com o intuito de frisar que a ontologia se comporta como se o ser que ela tem de dizer já estivesse sempre presente. $\mathrm{Na}$ esteira de Lacan e de Górgias ela nos diz que "é preciso inverter o sentido do sentido, que não vai do ser ao dizer, mas do dizer ao ser" (Cassin, 2017, p. 66). Para nós trata-se apenas de problematizar a relação entre o ser e o dizer que faz ver e falar o ser. Devemos colocar em questáo a posiçáo da ontologia e apontar para uma alternativa que não pretenda simplesmente excluir a ontologia. Talvez possamos entrever isto através de um pequeno desvio arbitrário e bem-humorado na palavra "dizer", desvio ou jogo de escrita que só teria valor por sua diferença com a própria palavra em questão. No horizonte desta discussão sobre o ser e o dizer poderíamos entrever a ideia de um diser em que a letra " $s$ " chamaria atenção para o fato de que o ser é um efeito do dizer. 
É verdade que com estas últimas considerações nós já estamos navegando em águas não-merleau-pontianas. Mas é verdade, também, que não devemos recusá-las por excederem os domínios do ser e apontarem para uma relativizaçáo da ontologia, particularmente do lugar que o Ser ocupa para a filosofia. É verdade, enfim, que com estas consideraçóes nós não saímos da filosofia, mas apenas circunscrevemos e delimitamos o alcance deste Ser escrito com maiúscula. Ao navegarmos em águas merleau-pontianas aprendemos que elas são ao mesmo tempo profundas e estão próximas do continente, por isto encontramos nelas uma tensão viva e constante entre os seres e o ser. Aprendemos que sua filosofia deve ser considerada, como ele diz a propósito das essências de Husserl, como uma rede que traz do fundo do mar os peixes e as algas palpitantes (Merleau-Ponty, 2016a, p. 16). Não se trata de recusar o discurso merleau-pontiano, trata-se de retomá-lo mais radicalmente naquilo que ele tem de mais sensível. Se por um lado precisamos minimizar o papel do Ser e da verdade, por outro, devemos cada vez mais fixar o fato de que esta filosofia dá lugar para a diferença e para relaçóes indiretas, para trocas e diálogos, ela é democrática. Através de uma atitude deste tipo Merleau-Ponty pretende nos fazer ver e falar indiretamente o ser. Ao regressar das fontes da experiência esse filósofo diz com palavras o silêncio do mundo. Enquanto filósofo, enquanto pensa e nos faz pensar, Merleau-Ponty também é pintor, já que pretende colocar o mundo diante de nossos olhos, mas ele também é escritor, já que pretende fazer isto com palavras. Pode ser que ele consiga, como o pintor e o escritor, nos fazer tomar gosto pelo olhar e pela voz. O importante é que ao contrário de fazer a filosofia se calar, enquanto filósofo ele nos faz pensar e falar quando liga a própria filosofia aos entes e a uma região específica do ser, mas também quando defende que a linguagem filosófica está ligada à expressão e à ação. Ele admira Husserl que não julgou a crise do alto, "como se ele não tivesse responsabilidade" (Id., 1996, p. 72). Ele defende que o filósofo e o escritor têm responsabilidades específicas, e que, ao falar, o filósofo também age e faz agir. Se pensarmos nas sempre atuais relaçóes do filósofo com a cidade, que não há filosofia sem alcance político e que mais do que nunca a ética e a política exigem toda nossa atenção, talvez esta responsabilidade falante e vigilante da filosofia seja uma das coisas boas que Merleau-Ponty nos deixou para retomar e levar adiante.

\section{Referências bibliográficas}

Cassin, B. (2017). Jacques, o sofista: Lacan, logos e psicanálise. Tradução Yolanda Vilela. Belo Horizonte: Autêntica Editora.

Cícero. (1835). Rhétorique a Herennius. Trad. M. Delcasso. Paris: Panckoucke. 
Freud. S. (2017). O chiste e sua relação com o inconsciente. Trad. Paulo César de Souza. São Paulo: Companhia das Letras.

Heidegger, M. (1985). Etre et temps. Trad. Emmanuel Martinau. Paris: Authentica. Lacan, J. (1975). Encore. Seuil: Paris.

Merleau-Ponty, M. (1968). Résumés de cours. Collège de France 1952-1960. Paris: Gallimard.

(1996). Sens et non-sens. Paris: Gallimard.

(1996). Notes de cours 1959-1960. Paris: Gallimard.

(1999). L'Eil et l'esprit. Paris: Gallimard.

(2000). Parcours deux 1951-1961. Lagrasse: Éditions Verdier.

(2012). La prose du monde. Paris: Gallimard.

(2013a). "Cinemá et psychologie" [1945]. In: Merleau-Ponty e l'estetica oggi. Organização de Mauro Carbone. Milão: Mimesis Edizioni.

. (2013b). La structure du comportement. Paris: Puf.

. (2013c). Recherches sur l'usage littéraire du langage. Genebra: MétisPress.

(2016a). Phénoménologie de la perception. Paris: Gallimard.

(2016b). Le visible et l'invisible. Paris: Gallimard.

Paulhan, J. (1941). Les fleurs de Tarbes ou La Terreur dans les Lettres. Paris: Gallimard.

teur.

(1997). Traité des figures, in Jacob Cow le pirate. Ardèche: Deyrolle Édi-

Quintiliano. (2016). Instituição Oratória. Tomo IV. Trad. Bruno Basseto. Campinas: Unicamp. 